Raff, R.A. (1987) Constraint, flexibility, and phylogenetic history in the evolution of direct development in sea urchins. Dev. Biol., 119: 7-19.

Raff, R.A. (1996) The Shape of Life. University of Chicago Press, Chicago, IL.

Raff, R.A., and T.C. Kaufman (1983) Genes, Development, and Evolution. McMillan, New York.

Rockman, M.V., and G.A. Wray (2002) Abundant raw material for cis-regulatory evolution in humans. Mol. Biol. Evol., in press.

Sanderson, M.J., and L. Hufford (eds.) (1996) Homoplasy: The Recurrence of Similarity in Evolution. Academic Press, San Diego, CA.

Segal, J.A., J.L. Barnett, and D.L. Crawford (1999) Functional analyses of natural variation in SP1 binding sites of a TATA-less promoter. J. Mol. Evol., 49: 736-749.

Smith, A.B., D.T.J. Littlewood, and G.A. Wray (1995) Comparing patterns of evolution: Larval and adult life history stages and small subunit ribosomal RNA of post-Paleozoic echinoids. Phil. Trans. R. Soc. Lond. B, 349: 1118
Strathmann, R.R. (1971) The feeding behavior of planktotrophic echinoderm larvae: Mechanisms, regulation and rates of suspension feeding. J. Exp. Mar. Biol. Ecol., 6: 109-160.

Strathmann, R. (1985) Feeding and nonfeeding larval development and life-history evolution in marine invertebrates. Ann. Rev. Ecol. Syst., 16: 339-361.

Strathmann, R.R. (1988) Functional requirements and the evolution of developmental patterns. In Echinoderm Biology: Proceedings of the Sixth International Echinoderm Conference (ed. by R.D. Burke, P.V. Mladenov, P. Lambert and R.L. Parsley), Balkema, Amsterdam, pp. 55-61.

Tabin, C.J., S.B. Carroll, and G. Panganiban (1999) Out on a limb: Parallels in vertebrate and invertebrate limb patterning and the origin of appendages. Am. Zool., 39: 650-663.

Villinski, J.T., J.C. Villinski, M. Byrne, and R.A. Raff (2002) Convergent maternal provisioning and life history evolution in echinoderms. Evolution, in review.

Wake, D. (1999) Homoplasy, homology and the problem of 'sameness' in biology. In Homology (ed. by G.R. Bock and G. Cardew), Wiley, Chichester, pp. 24-33.
Wedeen, C.J., and D.A. Weisblat (1991) Segmental expression of an engrailed-class gene during early development and neurogenesis in an annelid. Development, 113: 805-814.

Wilkins, A.S. (2002) The Evolution of Developmental Pathways. Sinauer, Sunderland, MA.

Wilson, A.C. (1975) Evolutionary importance of gene regulation. Stadler Symp., 7: 117-134.

Wray, G.A. (1992) The evolution of larval morphology during the post-Paleozoic radiation of echinoids. Paleobiology, 18: 258-287.

Wray, G.A. (1996) Parallel evolution of nonfeeding larvae in echinoids. Sys. Biol., 45: 308-322.

Wray, G.A., A.E. Bely (1994) The evolution of echinoderm development is driven by several distinct factors. Development Suppl., 97-106.

Wray, G.A., and C.J. Lowe (2000) Developmental regulatory genes and echinoderm evolution. Sys. Biol., 49: 28-51.

Wray, G.A., and D.R. McClay (1989) Molecular heterochronies and heterotopies in early echinoid development. Evolution, 43: 803-813.

Zakon, H. (2002) Convergent evolution on the molecular level. Brain Behav. Evol., 59: 250-261.

\title{
Subject Index Vol. 59, No. 5-6, 2002
}

Adaptation 273

Animal behavior 240

Birds 294

Cerebellum 312

Cerebellum-like structures 312

Cerebral cortex 262

Constraint 273

Convergence 250, 273, 312, 327

Cortex 262

Electric communication 240

- fish 240

Evolution 262, 294, 312

- of development 327

Frogs 240

G Protein-coupled receptor 273
Gap junctions 250

Glomerulus 273

Glutamate receptors 250

Homology 312, 327

Hox complex 327

$\mathrm{K}^{+}$channels 250

Larva 327

Mammals 294

Molecular evolution 250

$\mathrm{Na}^{+}$channels 250

Neuroethology 240

Odorant binding protein 273

Ontogeny 294

Opsins 250

Owls 240
Phylogeny 240

Prey capture 240

Primates 262

Pufferfish (Fugu) 250

Sensory transduction 273

Sound localization 240

Squirrels 262

Superior colliculus 262

Syngeny 312

Thalamus 262

Time coding 294

Tree shrews 262

Visual system 262 